\title{
Genetic and epigenetic loss of miR-31 activates NIK-dependent NF- $\kappa$ B pathway in Adult T-cell Leukemia
}

\author{
Makoto Yamagishi', Kazumi Nakano', Tadanori Yamochi', Ariko Miyake', Yayoi Kagami', Akihisa Tsutsumi', \\ Aiko Otsubo ${ }^{2}$, Seishi Ogawa ${ }^{2}$, Atae Utsunomiya ${ }^{3}$, Kazunari Yamaguchi ${ }^{4}$, Kaoru Uchimaru ${ }^{5}$, Toshiki Watanabe ${ }^{*}$ \\ From 15th International Conference on Human Retroviruses: HTLV and Related Viruses \\ Leuven and Gembloux, Belgium. 5-8 June 2011
}

Although crucial roles of microRNA have begun to emerge, detailed studies with ATL patients have not been achieved. Using 40 primary ATL samples and 22 samples of normal CD4+ T-cells, we determined the microRNA signatures of ATL and revealed loss of miR31 , which has recently been reported as a metastasisassociated miRNA. All ATL cases invariably showed undetectable or very low levels of miR-31, clearly implying that miR-31 loss is involved in ATL development.

As a novel miR-31 target gene, we identified NF- $\kappa$ B inducing kinase (NIK) that plays central roles in noncanonical signaling and constitutive activation of NF- $\kappa \mathrm{B}$ in various cancers, including ATL. Restoration of miR-31 downregulated the levels of NIK and NF- $\kappa$ B activity, resulting in reduction of malignant phenotypes, containing proliferative index, anti-apoptosis, and chemotaxis in ATL cells. Furthermore, lentivirus-introduced miR-31 could induce strong apoptosis in primary tumor cells freshly isolated from ATL patients, indicating pivotal functions of miR-31 as a tumor suppressor.

Global copy number profiling demonstrated that 21 cases out of 168 (12.5\%) have genomic loss of 9p21 containing miR-31 region. Furthermore, expression profiling and ChIP assay showed requirement of overexpression of histone methyltransferase in epigenetic suppression of miR-31 and aberrant NF- $\kappa$ B activation in primary ATL cells. Knockdown of methyltransferase complex restored the miR-31 expression and consequently inhibited NIKdependent NF- $\kappa \mathrm{B}$ cascade. These findings illustrated that genetic and epigenetic abnormalities link to NF- $\kappa \mathrm{B}$ activation through the loss of miR-31. Considering

\footnotetext{
* Correspondence: tnabe@ims.u-tokyo.ac.jp

${ }^{1}$ Graduate School of Frontier Sciences, The University of Tokyo, Tokyo, Japan Full list of author information is available at the end of the article
}

aberrant epigenomics associated with cancers, the emerging relationship provides us a conceptual advance in understanding the broad-acting oncogenic signaling.

\section{Author details}

'Graduate School of Frontier Sciences, The University of Tokyo, Tokyo, Japan. ${ }^{2}$ Faculty of Medicine, The University of Tokyo, Tokyo, Japan. ${ }^{3}$ Department of Haematology, Imamura Bun-in Hospital, Kagoshima, Japan. ${ }^{4}$ Department of Safety Research on Blood and Biologics, National Institute of Infectious Disease, Japan. ${ }^{5}$ Institute of Medical Science, The University of Tokyo, Tokyo, Japan.

Published: 6 June 2011

doi:10.1186/1742-4690-8-S1-A128

Cite this article as: Yamagishi et al:: Genetic and epigenetic loss of miR31 activates NIK-dependent NF- $\kappa$ B pathway in Adult T-cell Leukemia. Retrovirology 2011 8(Suppl 1):A128.

Submit your next manuscript to BioMed Central and take full advantage of:

- Convenient online submission

- Thorough peer review

- No space constraints or color figure charges

- Immediate publication on acceptance

- Inclusion in PubMed, CAS, Scopus and Google Scholar

- Research which is freely available for redistribution

Submit your manuscript at Submit your manuscript at
www.biomedcentral.com/submit C Biomed Central

\section{Biomed Central}

(c) 2011 Yamagishi et al; licensee BioMed Central Ltd. This is an open access article distributed under the terms of the Creative Commons Attribution License (http://creativecommons.org/licenses/by/2.0), which permits unrestricted use, distribution, and reproduction in any medium, provided the original work is properly cited. 